\title{
RESOURCES AND POTENTIAL OF AGRI-FOOD PRODUCTS WITH ADDED VALUE IN BRANIČEVO-PODUNAVLJE REGION
}

\author{
Branko Mihailović ${ }^{1}$, Ivana Radić Jean ${ }^{2}$ \\ *Corresponding authorE-mail: brankomih@neobee.net
}

A R T I C L E I N F O
Original Article
Received: 10 April 2019
Accepted: 03 August 2019
doi:10.5937/ekoPolj1903669M
UDC 631.559:338.439.01
(497.11 Braničevski okrug)

Keywords:

agriculture, agri-food products, agroindustry, added value, processing capacities

JEL: O21,Q13,Q15

\section{A B S T R A C T}

The paper explores the agricultural resources of the Braničevo-Podunavlje region and opportunities of agrifood products development with added value. In particular, the aim is to evaluate the following resources and potentials of the Region: the workforce and its knowledge and skills, used agricultural land, on-farm value-adding activities, local traditional food products, agricultural buildings and storage capacities and knowledge as well as innovation transfer in agriculture. In the research was used spatial and sectoral analysis of agricultural resources and potential for achieving more reliable answers to key questions that arise in the context of the analysis of valueadded agri-food products in Braničevo-Podunavlje region. The research's results show that the use of comparative advantages and traditions, which the $\mathrm{BP}$ region has in the field of agricultural production presupposes the transformation of domestic agriculture and all forms of business entities in this activity. In the coming period, emphasis must be placed on the development of agri-food products with added value, which is focused on meeting the needs and wishes of consumers, with an emphasis on innovation, quality, high level of food hygiene and food safety standards.

(C) 2019 EA. All rights reserved.

\section{Introduction}

Changing consumer lifestyle habits in urban areas of developed and emerging economies create demand for more value-added foods. People spend less time on cooking, relying more heavily on ready-to-eat and partially prepared food products ranged from raw salad mixes to pre-prepared meals from the grocery store (Smith et al., 2013). On the other hand, people are increasingly health conscious and they are willing to pay premium prices for

1 Branko Mihailović, Ph.D., Senior Research Associate, Institute of Agricultural Economics, Volgina Street no. 15, 11060 Belgrade, Serbia, phone number: +381 1169728 58, e-mail: brankomih@neobee.net, ORCID ID (https://orcid.org/0000-0002-2398-6568)

2 Ivana Radić Jean, PhD candidate, CIRAD, Agricultural Research for Development, Avenue Agropolis, 34398 Montpellier Cedex 5, France, phone number: 0033778796981, e-mail: ivana.radicjean@gmail.com, ORCID ID (https://orcid.org/0000-0003-4946-6437) 
healthy food, functional food and nutraceuticals (The APO, 2012). According to Acharya et al. (2017), value addition is a process in which for the same volume of a primary product, a high price is realized by means of processing, packing, upgrading the quality or other such methods. Also, perceived value is an important factor in affecting consumers' attitude and purchase intentions (Hsu et al., 2018). The U.S. Department of Agriculture (USDA) defined value-added agriculture as follows:

- A change in the physical state or form of the product (such as milling wheat into flour or making strawberries into jam).

- The production of a product in a manner that enhances its value, as demonstrated through a business plan (such as organically produced products).

- The physical segregation of an agricultural commodity or product in a manner that results in the enhancement of the value of that commodity or product (such as an identity preserved marketing system) (The Agricultural Marketing Resource Center, 2015).

Relating the motivation of value-added agriculture to consumer preferences helps farmers to think beyond the conventionally-produced agricultural or food products and analyze the opportunities to be financially rewarded for creating value for consumers (Lu, Dudensing, 2015). Ready-to-eat, organic, traditional and regionally branded food, grown and processed on farms as well as healthy, nutritionally improved and quality upgraded food products, resulted from technological advances in food processing, packaging and tracking creates new opportunities for agribusinesses and entrepreneurs in the food industry. On-farm valueadding activities can increase the income of farming households, while off-farm ones can create allied enterprises with employment opportunities (The APO, 2012). It is necessary to reassess the existing and development of new business and marketing strategies of agricultural producers, based on developmental abilities and strengths of the producers themselves, but also on knowing consumers' preferences, new technologies, marketing approaches and other modern market postulates of economy. Additionally, farmers can help customers to better understand the products (Bonadonna et al., 2019).

The Republic of Serbia has favourable natural conditions for development of heterogeneous agricultural production, since it is located at the most favourable area of northern latitude. Together with climate, land represents the most important natural condition for development of agriculture. The agricultural land makes $65.6 \%$ of the Serbian territory (SORS, 2013a). In accordance to the 2012 Census of agriculture (SORS, 2013b), the Republic of Serbia disposes with $3,437,423$ ha of used agricultural land ( 0.48 ha per capita). Even $73 \%$ of the used agricultural land are arable land and gardens. Free trade agreements (CEFTA, preferential export to the EU market, Free Trade Agreement with the Russian Federation, General Preferential System for the USA, etc), provide a chance to domestic producers and exporters to overcome the problem of small market along with realization of price competitiveness and increase of products quality. Almost a half of the total export directs to the EU market and realizes a significant surplus in exchange. The Free Trade Agreement with the Russian Federation provides a higher export of meat, milk and fruits on the 
Russian market, and at the same time, it is one of the greatest assets Serbia has in attracting foreign investments ${ }^{3}$. The structure of agricultural and food exports is unsatisfactory conventionally-produced raw agricultural commodities dominated the export. The most important export products of agricultural origin in 2017 were: maize (250.2 million euros), raspberries, etc. frozen (234.8 million euros), cigarettes containing tobacco (207.7 million euros), fresh apples (111.4 million euros) and other fruits, uncooked, boiled, frozen (95.4 million euros) (CCIS, 2018). Basic limiting factors for more significant and more efficient inclusion of food industry in the international market are:

(a) low level and structure of agricultural production, its high extensiveness, oscillation and low productivity, along with inefficient organization of trading channels, absence of long-term and firm contractual relations or proprietary connection between agricultural producers and food industry and insufficient respect of market signals.

(b) insufficient assortment of food products and insufficient level of added values to the products through greater role of knowledge, innovations, etc as well as different level of technical-technological equipment of food industry sectors (the most was invested in industry of oil, beer, dairy, confectionary and water processing while less investments were registered in industry for processing of sugar, meat, fruits and vegetables).

(c) vacillation of market products quality, whether due to lack of standards, or due to disrespect and weak control of the existing standards.

In the coming period, Serbian agrarian policy must be placed emphasis on the development of the food industry that is focused on meeting the needs and desires of consumers, with an emphasis on innovation, quality, high standards of food hygiene and food safety (Mihailović, Brzaković, 2018). Competitiveness of the national agro-food sector is based on the use of quality standards in the supply chain (Ćoćkalo et al, 2019). The guarantee of food safety and quality is a basic presumption for successful access to the domestic and foreign markets (Popović et al, 2017). There are great potentials for development of organic agriculture and organic foods which main characteristic is high quality, and for which is very interested international market (Simić, 2017). International market is also interested for high-value local, exotic or traditional agricultural and food products with protected geographical indications. Geographical indication is a sign used on products that have a specific geographical origin and possess qualities or a reputation that are due to that origin (WIPO, 2019). The legal certainty and reduction in unfair competition improve market access and increase prices of GI products (Vandecandelaere et al., 2018).

In addition to favorable natural conditions, BP region has a knowledge and tradition in agriculture, but the competitiveness of the sector is weak. Various weaknesses are present

3 All the advantages of free trade with the Russian Federation and other member-countries of the Customs Union (Byelorussia, Kazakhstan), Serbia should use until it accesses the EU, because after that, the signed free trade agreements will not take effect anymore. 
in the value chain, from low level of producer organization and innovative food processing to insufficiently expert and thoughtful marketing and promotion of regional products (RDA BP, 2011). According to the same source, food processing sector is characterized by exceptional diversity, so in the region there are dairies, slaughterhouses, confectionery, mills, production of alcoholic and non-alcoholic drinks, etc. However, there are still a number of unused potentials and opportunities for new investments in the food industry.

\section{Materials and methods}

An analysis of the resources and potential of agri-food products with added value in the BP region is based on the following data sources: available statistical data and statistical surveys of the Statistical Office of the Republic of Serbia, strategic development documents of the Republic of Serbia and the BP region, the Garden of Serbia project results of Regional Development Agency "Braničevo-Podunavlje" (2011) and researches of domestic and foreign authors in this thematic field. In the research was used spatial and sectoral analysis of agricultural resources and potential for achieving more reliable answers to key questions that arise in the context of the analysis of value-added agri-food products in Braničevo-Podunavlje region.

\section{Results and Discussion}

Braničevo-Podunavlje as the dominant rural region, characterized by rich natural resources, cultural and historical heritage, good geographical connection with key transport routes and international corridors, diversity of potentials for the development of various economic activities. Agriculture is one of the most important segments of the economy of the BP region, which, despite its potentials, is underused (RDA BP, 2016). Natural diversity has caused the development of different types of agricultural production (fruit and vegetables growing, cattle breeding), which are the basis for further development of the sector, respecting the requirements of the market and international standards. Traditional food processing industry in the BP region has lost significance during the privatization process.

The workforce and its knowledge and skills are certainly the most valuable resource for development of agriculture and food industry in BP region. Namely, in this Region there are a total of 9,247 registered individual farmers (SORS, 2018). Also, 45,824 managers at holdings are registered in total (SORS, 2013c). The level of qualifications is as follows: 33,043 managers have an only practical agricultural experience and 326 managers attended at agricultural courses. Agriculture, forestry and fishery sector employs $1.8 \%$ of total regional economy employment. The highest percentage of employees in BP economy is recorded in the processing industry (25.3\%) (SORS, 2018). In order to improve the competitiveness of the agricultural sector and encourage rural development in BP region it is necessary to implement adequate strategic measures and projects in the field of human resources development that include a greater connection between science and practice through reorganized advisory services, agricultural cooperatives and other associations of farmers, development and implementation of 
new knowledge and skills of farmers through advice, training, seminars, courses and support to young farmers in the modernization of the farm.

Used agricultural land. Fertile arable land prevails in the area of Stig plain, located between the City Pozarevac and the municipalities of Veliko Gradiste, Petrovac na Mlavi and Malo Crniće. In the eastern, forested hilly-mountainous part of the region, agricultural land is of lower grade, but there is a significantly higher share of meadows and pastures (RDA BP, 2011). The structure of used agricultural land of holdings in $\mathrm{BP}$ region is: kitchen garden 1,483 ha, arable land 166,985 ha, meadows and pastures 28,880 ha, fruit plantations 10,314 ha; vineyards 1,367 ha, nurseries 22 ha and other permanent plantations 33 ha (Table 1,2).

Table 1. Used agricultural area of holdings in BP region, by categories

\begin{tabular}{|c|c|c|c|c|c|c|c|c|}
\hline & \multirow{2}{*}{$\mathbf{A H}$} & \multirow{2}{*}{ UAA, ha } & \multicolumn{2}{|c|}{ Kitchen garden } & \multicolumn{2}{|c|}{ Arable land } & \multicolumn{2}{|c|}{$\begin{array}{c}\text { Meadows and } \\
\text { pastures }\end{array}$} \\
\hline & & & AH & ha & $\mathbf{A H}$ & ha & AH & ha \\
\hline Branicevo reg. & 26,361 & 135,748 & 12,959 & 838 & 24,433 & 105,186 & 11,991 & 25,025 \\
\hline \begin{tabular}{|l|} 
City of \\
Požarevac \\
\end{tabular} & 5,043 & 24,981 & 2,649 & 142 & 4,386 & 23,319 & 917 & 938 \\
\hline Požarevac & 4,427 & 22,666 & 2,264 & 120 & 3,857 & 21,107 & 871 & 923 \\
\hline Kostolac & 923 & 2,315 & 385 & 22 & 529 & 2,212 & 46 & 15 \\
\hline V.Gradište & 2,587 & 17,691 & 1,226 & 62 & 2,415 & 15,667 & 1,118 & 1,459 \\
\hline Golubac & 1,385 & 6,416 & 586 & 35 & 1,325 & 4,436 & 662 & 1,698 \\
\hline Žabari & 2,236 & 13,144 & 1,027 & 77 & 2,120 & 11,822 & 385 & 713 \\
\hline \begin{tabular}{|l} 
Žagubica \\
\end{tabular} & 3,145 & 18,893 & 1,451 & 69 & 2,985 & 6,956 & 2,612 & 11,260 \\
\hline Kučevo & 3,668 & 11,622 & 2,296 & 180 & 3,370 & 5,972 & 2,646 & 4,940 \\
\hline \begin{tabular}{|l|} 
Malo Crniće \\
\end{tabular} & 2,401 & 14,778 & 1,022 & 70 & 2,252 & 13,706 & 899 & 653 \\
\hline $\begin{array}{l}\text { Petrovac na } \\
\text { Mlavi }\end{array}$ & 5,896 & 28,221 & 2,702 & 205 & 5,580 & 23,309 & 2,752 & 3,362 \\
\hline Podunavlje reg. & 18,800 & 73,336 & 10,525 & 645 & 16,858 & 61,799 & 3,739 & 3,855 \\
\hline \begin{tabular}{|l|} 
Velika Plana \\
\end{tabular} & 5,225 & 18,994 & 3,344 & 210 & 4,860 & 17,481 & 423 & 777 \\
\hline Smederevo & 6,877 & 26,560 & 3,149 & 172 & 5,708 & 20,514 & 1,008 & 1,077 \\
\hline \begin{tabular}{|l} 
Sm. Palanka \\
\end{tabular} & 6,698 & 27,782 & 4,032 & 262 & 6,290 & 23,803 & 2,308 & 2,001 \\
\hline BP region & 45,161 & 209,084 & 23,484 & 1,483 & 41,291 & 166,985 & 15,730 & 28,880 \\
\hline
\end{tabular}

Source: SORS, 2013b

Table 2. Used agricultural land of holdings in BP region, by categories

\begin{tabular}{|l|r|r|r|r|r|r|r|r|}
\hline & \multicolumn{9}{|c|}{ Permanent plantations } \\
\cline { 2 - 10 } & \multicolumn{1}{|c|}{ Fruit plantations } & \multicolumn{2}{c|}{ Vineyards } & \multicolumn{2}{c|}{ Nurseries } & \multicolumn{2}{c|}{ Other } \\
\cline { 2 - 10 } & AH & \multicolumn{1}{|c|}{ hH } & \multicolumn{1}{c|}{ ha } & AH & \multicolumn{1}{c|}{ ha } & AH & \multicolumn{1}{c|}{ ha } \\
\hline Branicevo region & 12,461 & 4,020 & 5,445 & 638 & 31 & 14 & 122 & 27 \\
\hline City of Požarevac & 1,851 & 478 & 884 & 99 & 6 & 6 & 2 & 0 \\
\hline Požarevac & 1,630 & 426 & 789 & 87 & 5 & 6 & 3 & 0 \\
\hline Kostolac & 221 & 52 & 95 & 11 & 1 & 3 & - & - \\
\hline Veliko Gradište & 1,221 & 390 & 893 & 113 & - & - & 4 & 1 \\
\hline Golubac & 637 & 179 & 481 & 65 & 2 & 0 & 11 & 2 \\
\hline
\end{tabular}




\begin{tabular}{|l|r|r|r|r|r|r|r|r|}
\hline & \multicolumn{9}{|c|}{ Permanent plantations } \\
\cline { 2 - 10 } & \multicolumn{1}{|c}{ Fruit plantations } & \multicolumn{2}{|c|}{ Vineyards } & \multicolumn{2}{c|}{ Nurseries } & \multicolumn{2}{c|}{ Other } \\
\cline { 2 - 10 } & AH & \multicolumn{1}{|c}{ hH } & \multicolumn{1}{c|}{ ha } & AH & \multicolumn{1}{c|}{ hH } & \multicolumn{1}{c|}{ ha } \\
\hline Žabari & 1,158 & 423 & 583 & 106 & 4 & 2 & 2 & 0 \\
\hline Žagubica & 1,730 & 603 & 70 & 5 & - & - & - & - \\
\hline Kučevo & 1,530 & 471 & 645 & 52 & 4 & 4 & 7 & 3 \\
\hline Malo Crniće & 1,037 & 300 & 491 & 49 & - & - & - & - \\
\hline Petrovac na Mlavi & 3,297 & 1,175 & 1,398 & 149 & 15 & 2 & 96 & 19 \\
\hline Podunavlje region & 6,813 & 6,294 & 3,198 & 729 & 10 & 8 & 11 & 6 \\
\hline Velika Plana & 1,370 & 398 & 750 & 126 & - & - & 4 & 1 \\
\hline Smederevo & 2,912 & 4,412 & 1,313 & 381 & 3 & 3 & 2 & 1 \\
\hline Smed. Palanka & 2,531 & 1,484 & 1,135 & 221 & 7 & 5 & 5 & 5 \\
\hline Total BP region & 19,274 & 10,314 & 8,643 & 1,367 & 41 & 22 & 133 & 33 \\
\hline
\end{tabular}

Source: SORS, 2013b

Production structure (Census of Agriculture, SORS, 2013b):

- From vegetable crops, on the largest number of areas are grown carrots, cabbage, kale and carfiol, which participate in the total area at the national level from 6,16-7,78\%. Within the Region, the most important areas are those under paprika, bostan and peas. Out of a total of 33,232 ha of areas under vegetable crops that are concentrated in Smederevo, Velika Plana and Veliko Gradište, only $6.27 \%$ are protected areas.

- With areas under orchards, the Region (primarily Smederevo, Smederevska Palanka and Petrovac on Mlava) participates in the national scale with approximately $6 \%$, of which as many as $28.33 \%$ of peach plantations and $9.08 \%$ of apple crops in Serbia are in the Region, as and $8.31 \%$ of the total walnut plantations at the national level.

- In addition to these significant areas in the Region, they are under planted plums, cherries and pear trees. Although the share of the Region, when the area under vineyards is only $6,17 \%$ of the total area at the national level, viticulture has been on the rise for the last decade.

- $\quad$ For the purposes of the used agricultural land dominated by fields and gardens that cover almost $80 \%$ of the area, where fodder plants (clover and alfalfa) and cereals (wheat and barley) are mostly grown. They are least represented in mountainous rural areas (Žagubica, Kučevo, Golubac), where dominant meadows and pastures, that is, forest land that makes up almost $14 \%$ of the total available agricultural land of the Region.

On-farm value-adding activities are poorly developed. Only 3,259 or $7.1 \%$ of households are engaged in some additional profitable activity, which is significantly lower than national average of $12.4 \%$ (SORS, 2013c). Approximately $80 \%$ deal with different types of processing of agricultural products, of which the most important is the milk processing sector (Table 3). 
Table 3. Agricultural holdings dealing with the processing of agricultural products

\begin{tabular}{|l|r|r|r|r|r|}
\hline $\begin{array}{c}\text { Region / District / } \\
\text { Municipality }\end{array}$ & AH & $\begin{array}{c}\text { meat } \\
\text { processing }\end{array}$ & \multicolumn{1}{c|}{$\begin{array}{c}\text { milk } \\
\text { processing }\end{array}$} & $\begin{array}{c}\text { processing } \\
\text { of fruits and } \\
\text { vegetables }\end{array}$ & $\begin{array}{c}\text { processing of } \\
\text { other agricultural } \\
\text { products }\end{array}$ \\
\hline Braničevo & 1,980 & 138 & 1,099 & 138 & 172 \\
\hline Požarevac & 469 & 6 & 373 & 21 & 8 \\
\hline Veliko Gradište & 107 & 5 & 36 & 18 & 7 \\
\hline Golubac & 187 & 6 & 135 & 30 & 1 \\
\hline Žabari & 233 & 3 & 36 & 5 & 7 \\
\hline Žagubica & 281 & 7 & 156 & 6 & 19 \\
\hline Kučevo & 190 & 1 & 106 & 14 & 120 \\
\hline Malo Crniće & 172 & 3 & 103 & 38 & 69 \\
\hline Petrovac na Mlavi & 341 & 107 & 154 & 264 & 45 \\
\hline Podunavlje & 1,279 & 93 & 663 & 54 & 16 \\
\hline Velika Plana & 316 & 60 & 88 & 105 & 8 \\
\hline Smederevo & 411 & 21 & 248 & 406 & 241 \\
\hline Sm. Palanka & 552 & 12 & 327 & & \\
\hline BP region & 3,259 & 231 & 1,762 & 402 & \\
\hline
\end{tabular}

Source: RDA BP, 2016

Natural diversity has caused the development of different types of agricultural production (farming, vegetables, fruit growing, cattle breeding), which are the basis for further development of the sector, while respecting the requirements of the market and international standards (RDA BP, 2016).

Organic production is significantly represented: according to the records of the Ministry of Agriculture and Environmental Protection, in 2014, 5 producers from the region were involved in organic production (293 at the level of Serbia), mainly plant production of berries, mushrooms, self-herbs and aromatic plants, but also seed production of several products mentioned (RDA BP, 2016). Organic agriculture gets more and more important by bringing man closer to nature, from which he has grown, he also makes almost complete harmony with the requirements of environmental protection and finally, enables the population to feed products that are produced by natural processes, using organic and mineral matter. Promotion and sale of organic products require particular approach to introduce customers about the branding, packaging and advantages in comparison to conventional products (Dašić et al., 2019).

In the Region, several local traditional food products are produced (cheese, honey, brandy and wine, various meat products, etc.). Some of them have registered indications of geographical origin (Appelation of Origin - AO or Geographical indication - GI)4:

- Požarevačka kobasica - Sausage from Pozarevac (Appelation of Origin - AO, Geographical area: Region along the Danube River),

4 According to the Law on Indications of Geographical Origin (Official Gazette of the Republic of Serbia - OG RS, No 18/2010). 
- Homoljski ovčiji sir - Sheep cheese from Homolje (AO, Geographical area: District of Branicevo, municipality Zagubica in the mountains of Homolje).

- Homoljski kozji sir - Goat cheese from Homolje (AO, Geographical area: District of Branicevo, municipality Zagubica in the mountains of Homolje).

- Homoljski kravlji sir - Cow cheese from Homolje (AO, Geographical area: District of Branicevo, municipality Zagubica in the mountains of Homolje).

- Homoljski med - Honey from Homolje (AO, Geographical area: The mountains of Homolje).

- Đerdapski med - Djerdap honey (GI, Geographical area: Djerdap area) (The IPO of the RS, 2016, 2019).

These products are recognizable at the national level and also have the potential for developing new (niche) export markets. It is necessary to support agricultural holdings with market propulsion and export programs of agricultural production.

Other profitable activities participate in the income of almost $60 \%$ of households with less than $10 \%$, and only about $5 \%$ of them generate more than $50 \%$ of their income (RDA BP, 2016).

Agricultural buildings and storage capacities in BP region. Farms of the BP region registered the following number of storage and processing capacities (Table 4).

Table 4. Agricultural buildings and storage capacities at holding in BP region

\begin{tabular}{|c|c|c|c|c|}
\hline \multirow[b]{2}{*}{ Storage and processing capacities } & \multicolumn{2}{|c|}{ Braničevo region } & \multicolumn{2}{|c|}{ Podunavlje region } \\
\hline & Total & $\begin{array}{c}\text { Used } \\
\text { capacities }\end{array}$ & Total & $\begin{array}{c}\text { Used } \\
\text { capacities }\end{array}$ \\
\hline Maize cribs, $\mathrm{M}^{3}$ & 21,017 & 421,404 & 13,439 & 216,803 \\
\hline Barns, $\mathrm{M}^{3}$ & 9,271 & 129,575 & 6,978 & 94,215 \\
\hline Silos, $\mathrm{T}$ & 128 & 37,330 & 85 & 3,997 \\
\hline Drying facilities, $\mathrm{M}^{3}$ & 36 & 6,809 & 18 & 1,596 \\
\hline Buildings for storing silage, $\mathrm{M}^{3}$ & 790 & 37,456 & 868 & 38,188 \\
\hline $\begin{array}{l}\text { Buildings for agricultural machinery and } \\
\text { equipment, } \mathrm{M}^{2}\end{array}$ & 15,356 & 894,258 & 7,416 & 372,074 \\
\hline Coolers, $\mathrm{M}^{3}$ & 71 & 2,798 & 342 & 54,295 \\
\hline Building for cattle housing, number of places & 16,932 & 34,951 & 8,976 & 19,891 \\
\hline Buildings for housing pigs, number of places & 24,114 & 173,491 & 15,124 & 105,731 \\
\hline Facilities for lying hens, number of places & 13,613 & 454,343 & 8,459 & 552,773 \\
\hline $\begin{array}{l}\text { Buildings for housing other livestock, number } \\
\text { of places }\end{array}$ & 9,736 & 180,608 & 4,272 & 97,469 \\
\hline Machine calibration and vacuum packing & 22 & 19 & 26 & 24 \\
\hline
\end{tabular}

Source: SORS, 2013c

Launchers of the food industry and the agro-business sector are: "Bambi", "Water escargot", "Union MZ, Požarevac", "Ishrana Smederevo", "Zitostig", "Fruvita", "Vodeprodukt", "100\%", "Slaughter Plan" and "Napredak" A.D. Velika Plana (MSP- 
NE SERBIA, 2009). Lately, some new companies are emerging in the region - examples of good practice in food production, which the volume of production by taking over the holdings and progressing in the value chain from production to processing and marketing in food production. However, the number of processing capacities is insufficient.

Bearing in mind the insufficient industrial capacities for the processing of agricultural products, it is necessary to support the development of new processing capacities according to the available raw commodities and market demands. This can be achieved by investing in the production, marketing and introduction of a quality system in accordance with EU standards. It is necessary to foresee the development of a program of production that would include all phases of the reproduction unit starting from primary production, through industrial processing and transport to the consumption of all major agricultural products.

Looking at trends in the international market, and bearing in mind the achieved level of production and competitiveness of domestic producers, it can be concluded that, on the assumption of meeting the quality control standards on the world market in terms of export of agricultural products, we are competitive only if we differentiate the offer, in terms of export of high quality products, with brand and / or indices of autochthonous origin. Namely, domestic producers of agro-food products can only build their export opportunity using the modern concept of competitiveness, which means creating a competitive advantage with quality and innovation, and differentiating the offer. In the following period, agrarian policy must emphasize the development of the food industry aimed at satisfying the needs and wishes of consumers, with an emphasis on innovation, quality, high standards of hygiene and food safety and food safety (Mihailović, Brzaković, 2018). There are great opportunities and potentials for the development of the domestic food industry in the field of organic foods production whose main characteristic is high quality, and for which the international market is very interested.

Knowledge and innovation transfer in agriculture. There is a relationship between knowledge management capabilities and successful open innovation within agri-food businesses (Cillo et al., 2019). Rapid technological development and innovation offers the prospect of meeting future food needs sustainably. However, this can only be achieved through discerning public policies, increased investments and public-private partnerships, which exploit the opportunities for maintaining current levels of productivity, sustainably raising yields, and reducing poverty and food insecurity (FAO, 2017). Response to these changes requires significant investment by the food industry in research and development, plants and equipment, and consumer outreach (Nikolić, Brankov, 2018). The quality of equipment and techniques for research in Serbia lags behind the European average. Although, the existing scientific and educational institutions have relatively high quality personnel, who had achieved a series of internationally recognized results: new sorts and breeds, scientific papers and technical solutions (MAEP, 2014). Product and service innovation has the greatest share in innovations introduced in the Republic of Serbia (26.9\%). The largest share of expenditures goes for procurement of machines, equipment and software (71.4\%). State financial support (in the form of tax credits, grants, subsidized loans or loan guarantees) was given to $12.5 \%$ of business entities - innovators (SORS, 2017). 
Transfer of knowledge in agriculture conducts through the system of formal education at all levels (from secondary education to $\mathrm{PhD}$ studies) and different forms of trainings organized by the educational and research institutions and organizations, AESSs, private companies, project units, media, etc. According to the Strategy of Agriculture and Rural Development of the Republic of Serbia 2014-2020 (OG RS, No. 85/14), the existing structure and the system of knowledge transfer are not sufficiently efficient to meet adequately the needs for more dynamic technical-technological restructuring of agricultural sector.

There is obviously a lack of knowledge and sources for introducing new technologies in agricultural production of BP region, although there are educational and R\&D institutions related to agriculture (Vegetable Institute, Veterinarian Institute for Reproductive and Artificial Insemination, Veterinary Specialist Institute, Superior Seeds, Institute for Agriculture in Pozarevac and Smederevo and Secondary and Higher Agricultural Schools (MSP-NE SERBIA, 2009). The possibilities provided by the private-public partnerships and other actors (cooperative associations, private consulting economic entities and agencies, NGO sector and others) have not been used. Therefore it should support the workshops, conferences, demonstration activities, information activities and the programs of short-term exchange or visit to the agricultural holdings.

\section{Conclusions}

The use of comparative advantages, which the BP region has in the field of production of agri-food products with added value presupposes the transformation of domestic agriculture and all forms of business entities in this activity. These transformation processes must go towards rethinking existing and developing new business and marketing strategies of agricultural producers, based on the developmental abilities and strengths of the manufacturers themselves, but also on the knowledge of consumer preferences, new technologies, marketing approaches and the use of quality standards as a basic presumption for successful access to the domestic and foreign markets.

In such conditions, respecting the market approach, that is, constant and intense changes in the market, is the first and basic assumption in which there would be a rational formulation of new marketing strategies, different from competitors precisely in terms of inventiveness, technology and quality. By producing competitive agri-food products, agriculture in th BP region would ensure sufficient income for family farms, focusing its activities on meeting the needs and preferences of consumers and working closely with the food processing industry.

\section{Acknowledgements}

Paper is a part of research within the project no. III 46006 - Sustainable agriculture and rural development in the function of accomplishing strategic objectives of the Republic of Serbia in the Danube region, financed by the Ministry of Education, Science and Technological Development of the Republic of Serbia, project period: 2011-2019; and the project: The Taste of Region - Promoting agri-food products with added value to improve economic capacities of family households, Regional Development Agency Braničevo-Podunavlje, Požarevac, 2018 November - 2019 February. 


\section{Conflict of interests}

The authors declare no conflict of interest.

\section{References}

1. Acharya, V., Shukla, S. \& Jain, S. (2017). Agri-produce processing and value addition for nutrition security. International Journal of Applied Home Science, 4(7-8), 611-616.

2. Agricultural Marketing Resource Center. (2015). USDA Value Added Ag Definition. Available at: http://www.agmrc.org/business_development/getting_ prepared/valueadded_agriculture/articles/usda-value-added-ag-definition/.

3. Bonadonna, A., Matozzo, A., Giachino, C. and Peira, G. (2019). Farmer behavior and perception regarding food waste and unsold food, British Food Journal, 121 (1): 89103. doi: https://doi.org/10.1108/BFJ-12-2017-0727.

4. Cillo, V., Rialti, R., Bertoldi, B. and Ciampi, F. (2019). Knowledge management and open innovation in agri-food crowdfunding, British Food Journal, 121(2): 242-258. doi: https://doi.org/10.1108/BFJ-07-2018-0472.

5. Dašić, G., Radosavac, A., Knežević, D., Đervida, R. (2019). Preferences of customers and improvement of production and sales of organic products in Serbia, Economics of Agriculture, 66 (1), 127-142. doi:10.5937/ekoPolj1901127D.

6. Ćoćkalo, D., Đorđević, D., Kavalić, M., \& Bešić, C. (2019). Implementation of certification schemes in the Balkan agro-food sector, Economics of Agriculture, 66 (1), 77-88, doi:10.5937/ekoPolj1901077C.

7. Lu, R., \& Dudensing, R. (2015). What Do We Mean by Value-added Agriculture? Choices, 4th Quarter, 30(4), 1-8. Available at: http:/www.choices magazine.org/ choices-magazine/submitted-articles/what-do-we-mean-by-value-added-agriculture.

8. Mihailović, B., \& Brzaković, T. (2018). Knowledge and Innovation Transfer in Agribusiness. Institute of Agricultural Economics, Belgrade.

9. Ministry of Agriculture and Environmental Protection of the Republic of Serbia (MAEP). (2014). IPARD II program for Serbia 2014-2020.

10. Nikolić I., \& Brankov T. (2018). Forces Influencing Poor Performance of Serbian Food Industry. Industrija, 46 (4), 127-143.

11. Official Gazette of the Republic of Serbia No. 85/14. Strategy of Agriculture and Rural Development of the Republic of Serbia for the period 2014-2020.

12. Official Gazette of the Republic of Serbia, No 18/2010. Law on Indications of Geographical Origin.

13. Popović, V., Vuković, P., \& Ćosić, M. (2017). Food safety and quality policy in the Republic of Serbia. Economics of Agriculture, 64 (4), 1607-1617.

14. Regional Development Agency Braničevo-Podunavlje (RDA BP). (2016). Regional Rural Development Strategy for Braničevo-Podunavlje 2016-2020. Požarevac.

15. Regional Development Agency Braničevo-Podunavlje (RDA BP). (2011). The Garden of Serbia Project. 
16. MSP-NE SERBIA. (2009). Regional Development Strategy of Braničevo-Podunavski Region for the period 2009-2013. Program for Support to Municipalities of North-East Serbia, February, 2009.

17. Simić, I. (2017). Organic Agriculture in Serbia At a Glance 2017. National Association Serbia Organica, Belgrade.

18. Smith, L. P., Ng, S. W., \& Popkin, B. M. (2013). Trends in US home food preparation and consumption: analysis of national nutrition surveys and time use studies from 1965-1966 to 2007-2008. Nutrition journal, 12, 45. doi:10.1186/1475-2891-12-45.

19. Statistical Office of the Republic of Serbia (SORS). (2018). Municipalities and regions in the Republic of Serbia 2018, Belgrade.

20. Statistical Office of the Republic of Serbia (SORS). (2017). Regions in the Republic of Serbia 2017, Belgrade.

21. Statistical Office of the Republic of Serbia (SORS). (2013a). Municipalities and regions in the Republic of Serbia 2013, Belgrade.

22. Statistical Office of the Republic of Serbia (SORS). (2013b). Census of Agriculture 2012, Agriculture in the Republic of Serbia, Volume 1, Belgrade.

23. Statistical Office of the Republic of Serbia (SORS). (2013c). Census of Agriculture, Volume 2, Belgrade.

24. The Asian Productivity Organization (APO). (2012). Value addition to agricultural products for new markets. APO News, September-October 2012. Available at: http:// www.apo-tokyo.org/publications/wp-content/uploads/sites/5/2012_Sep-Oct_p6b.pdf.

25. The Chamber of Commerce and Industry of Serbia (CCIS). (2018). Bulletin 2018. Center for Strategic Analysis, Analytics, Planning and Publications, Belgrade.

26. The Food and Agriculture Organization of the United Nations (FAO). (2017). The future of food and agriculture - Trends and challenges, FAO Rome.

27. The Intellectual Property Office of the Republic of Serbia (IPO). (2019). The List of the Indications of Geographical Origin registered in the Intellectual Property Office. Available at: http://www.zis.gov.rs/intellectual-property-rights/ inidications-ofgeographical-origin/list-of-igo.91. html.

28. The Intellectual Property Office of the Republic of Serbia (IPO). (2016). Register of Indications of geographical origin. Available at: http://www.zis.gov. rs/intellectualproperty-rights/inidications-of-geographical-origin/register-of-igo. 1160.html.

29. Vandecandelaere, E., Teyssier, C., Barjolle, D., Jeanneaux, P., Fournier, S., \& Beucherie, O. (2018). Strengthening sustainable food systems through geographical indications. An analysis of economic impacts. Rome: FAO.

30. World Intellectual Property Organization (WIPO). (2019). Geographical Indications. Available at: https://www.wipo.int/geo_indications/en/. 